\title{
Contribution of digital storytelling to creative thinking skills
}

\author{
Nesime Ertan Özen \\ National Ministry of Education, Uşak, Turkey, nesimeertan@gmail.com \\ Erol Duran \\ Uşak University Faculty of Education Department of Primary Education, Uşak, Turkey, \\ erolduran@gmail.com
}

\begin{abstract}
The aim of this study is to reveal the contribution of digital storytelling to the creative thinking skills of middle school seventh grade students. The study was designed as a mixed method research. The data were obtained from the digital stories created by the students through block-based coding, video recordings and student interviews. According to the findings, it was found that there are developments in fluency, originality, imagination, analytical thinking, different perspective, media elements and content dimensions. Similarly, it was found that there was an increase in the permanence test score average. The students stated that they found digital storytelling activities fun, they improved in different perspectives of critical thinking, multimedia elements made the stories attractive and the story elements were more easily noticed. It was stated that digital storytelling activities had a positive effect on Turkish lesson. During the process, student interactions in the classroom developed and they became more eager to participate in the digital storytelling process. These results show that digital storytelling contributes to creative thinking skills.
\end{abstract}

\section{Dijital hikâye oluşturmanın yaratıcı düşünme becerisine katkısı}

ÖZ Araştırmanın amacı dijital hikâye oluşturmanın ortaokul 7. sınıf öğrencilerinin yaratıcı düşünme becerisine katkısını ortaya koymaktır. Bu çalışma karma yöntem olarak tasarlanmıştır. Çalışmanın verileri öğrencilerin blok kodlama yoluyla oluşturdukları dijital hikâyelerden, süreçte yapılan video kayıtlarından ve uygulama sonunda gerçekleștirilen öğrenci görüşmelerinden elde edilmiştir. Yapılan analiz sonucu elde edilen bulgulara göre akıcılık, özgünlük, hayal gücü, analitik düşünme, farklı bakış açısı, medya unsurları ve içerik boyutlarında hikâyelerden elde edilen ortalama puanlarda gelişme olduğu görülmüştür. Benzer şekilde kalıcılık testi puan ortalamasında artış olduğu belirlenmiştir. Yarı yapılandırılmış görüşmelerden elde edilen bulgulara göre öğrenciler genel anlamda dijital hikâye oluşturma etkinliklerini eğlenceli bulduklarını, yaratıcı düşünmenin farklı boyutlarında gelişme gösterdiklerini, çoklu ortam ögelerinin hikâyeyi güzelleştirdiğini, hikâye unsurlarının daha kolay fark edildiğini belirtmişlerdir. Dijital hikâye olușturma etkinliklerinin Türkçe dersi üzerinde olumlu etkisinin olduğu belirtilmiştir. Süreç içerisinde sınıfta öğrencilerin etkileşimleri gelişmiş, dijital hikâye oluşturma sürecine katılma istekleri artmıştır. Elde edilen bu sonuçlar dijital hikâye anlatımının yaratıcı düşünme becerisine katkısı olduğunu göstermektedir.

Anahtar $\quad$ Dijital hikâye, Hikâye, Programlama becerisi, Türkçe eğitimi, Yaratıcı düşünme becerisi

Citation: $\quad$ Ertan-Özen, N., \& Duran, E., (2021). Contribution of digital storytelling to creative thinking skills. Turkish Journal of Education, 10(4), 297-318 https://doi.org/10.19128/turje.909865 


\section{INTRODUCTION}

Today, the internet and digital devices make it easy to access a lot of information, enable us to shape our knowledge and take action as a result. The importance of digital media has become undeniable with the development of technology. With this development, not only our reading and writing skills but the way we use our listening and speaking skills has changed. It is inevitable that the generation that is so closely related to technology will benefit from it.

Along with digital literacy, we see an individual with the skills of questioning, analytical thinking, finding different solutions, and creative thinking. It is known that children are creative by nature and therefore it is important to reveal and develop their creative thinking skills. Creativity in children can be developed by providing the right resources and creating environments where they can freely use their abilities. It is thought that the importance of new media technologies has increased here.

Technology supported learning environments should be arranged according to the constructivist approach that enables students to develop their creativity skills (Lea et al., 2003). Creative thinking is "aimed at obtaining new images, combining and separating them, transferring them to the material, thinking on the material, establishing qualitative relationships between lines, shapes, colors, finding spatial, expressive and aesthetic arrangements" (Kırışoğlu, 2002). Burke (2012), who described the computer as a "new and improved pen", stated that creative, critical and collaborative writing can be done with these digital devices. Digital stories are narratives that contribute to digital literacy and storytelling (Hartley \& McWilliam, 2009). Ohler (2008) stated that digital storytelling is a creative process in which traditional story is combined with digital technology. Digital stories generally emerge by combining the art of storytelling with various multimedia tools such as audio, visual and video (Robin, 2006; 2008). Digital stories which are multimodal digital texts (Hull \& Nelson, 2005) are seen as a combination of traditional storytelling and multimedia technologies (Normann, 2011). Students participate in the process by combining visual and written text through research, analysis, creation, and merging in the digital story creation process (LaFrance \& Blizzard, 2013). Digital stories created by students require a process in which they are active. In digital storytelling, individuals do not remain in the position of listeners, they shape their stories, interact with their stories and use information and communication technologies as a storytelling tool (Dorner et al., 2002). Thanks to digital stories formed by the combination of technology with creativity, students' seeing and hearing and perceiving the world in different ways has been stated as an important feature of using digital stories in education (Toki \& Pange, 2014). Jakes and Brennan (2005) stated that with digital stories, students experience a quality learning experience that first begins with the writing process, and that with the inclusion of technology, they experience a learning process that is more than learning without technology. In addition, it was stated that digital stories improve students' visual and multimedia literacy skills, communication, creativity, technology and information literacy skills, and help students to write more effectively by providing visualization of the text. Miller (2009) stated that digital stories have benefits such as increasing motivation and personalizing the learning experience, especially in students who show less success in reading and writing. Kajder (2004) stated that digital stories improve students' literacy skills and enable them to work as a director, artist, programmer, screenwriter and designer instead of just reading or writing.

Digital media technologies are used to create digital stories (Vinayakumar et al., 2018). When the literature on digital story creation is examined, it is seen that digital stories are mostly created with desktop computer software such as Windows Movie Maker, Windows Photo Story or iMovie (Lasica, 2006; Doğan, 2007; Sadik, 2008; Barrett, 2006; Microsoft, 2010; Wang \& Zhan , 2010; Xu et al., 2011; Hung et al., 2012; Yang \& Wu, 2012). However, in recent studies, it is seen that block based programming is used to introduce digital story creation to students from kindergarten to 12th grade (Resnick et al., 2009; Moenig \& Harvey, 2012). 
It has been stated that higher order thinking skills of students can be developed with computer programming today, where studies are concentrated on developing these skills (Fessakis et al., 2013; Kafai \& Burke, 2014). With the idea that coding is a 21 st century skill that every student should acquire, studies have been carried out in this area in recent years (Baz, 2018). It shows that some countries are starting to include coding in their curricula. In seven countries (Bulgaria, Czech Republic, Denmark, Portugal, Slovakia, Spain, England) coding training in certain fields has been made compulsory and is generally integrated into the information and technology course. Knowledge of simple programming has become compulsory in physics, chemistry and mathematics curricula in Denmark. A total of 12 countries, including Bulgaria, Cyprus, the Czech Republic, Denmark, Estonia, Greece, Ireland, Italy, Lithuania, Poland, Portugal and the United Kingdom, have integrated coding into their curricula (Balanskat \& Engelhardt, 2015).

Learning to code enables students to be not only consumers of the technology they use, but also creators. It is thought that while children are coding, they will realize that there is usually more than one way to solve a problem, and they can develop basic skills such as problem solving and critical thinking. This whole process, such as analyzing and discussing critical thinking and problem solving processes, also requires language practice. This study is important in terms of developing creative thinking, establishing a link between today's technologies and mother tongue education, researching digital storytelling in mother tongue education and storytelling through computer coding. It is also considered to be important in integrating Turkish education with current technologies.

In this study, it is thought that creating a digital story within the framework of 21 st century literacy skills will contribute to creative thinking skills. Therefore, in our study, it was aimed to investigate the contribution of creating digital stories to creative thinking skills. The sub objectives of this study are listed below.

1. Does digital story creation contribute to the creative thinking skills of middle school seventh grade students?

2. Do digital story creation activities ensure that creative thinking skills are permanent?

3. What are the student views on digital story creation?

4. What has been observed in the social environment, activity process, verbal and nonverbal communication process dimensions in the digital story creation process?

\section{METHOD}

\section{Research Model}

Mixed method was used in the study. Mixed method study is a study in which at least one quantitative method and one qualitative method are used to collect, analyze and report the findings of the research in a single study (Greene et al., 1989). In the mixed method, quantitative and qualitative methods complement each other and enable a more robust analysis by taking advantage of the strengths of each (Greene et al., 1989; Miles \& Huberman 1994; Greene \& Caracelli, 1997). Creswell et al. (2003) identified six most frequently types of designs: three sequential and three concurrent six designs. In this study, one of the mixed method research designs, nested design was used. The quantitative data set can form the main data set in nested design while the qualitative data set can form the second data set that supports the quantitative data or the qualitative data set can form the main data set, while the quantitative data set can act as the supporting data set. In this respect, quantitative and qualitative data sets are used as supporting each other in nested design (Creswell \& Clark, 2007). The reason why this research was designed with a mixed method is that the works to be done using digital storytelling have a structure that requires multiprocess.

In mixed method research, it is aimed to look at the research process and the data obtained from a plural 
perspective by bringing together quantitative and qualitative perspectives (Gay et al., 2006; Creswell \& Clark, 2007).

\section{Study Group}

The study group consists of 20 middle school students, studying at seventh grade, selected with purposeful sampling method, which is one of the nonrandom sampling methods. In purposeful sampling, the researchers choose the people most suitable for their purpose (Balc1, 2013). Therefore, the study group consists of students who learn coding during one semester of the academic year. Note that the ethical committee approval of the study was obtained from the Social and Humanities Scientific Research Ethics Committee at Uşak University (Approval Number is 2019-34).

Duran and Ertan Özen (2018) investigated the objectives in the Turkish course curriculum in the context of digital literacy skills and it was found that the number of objectives related to digital literacy was at the seventh and eighth grades at most. For this reason, it was deemed appropriate to constitute the study group of our research from seventh grade students.

\section{Data Collection Tools}

In the research, "Creative Thinking Skill in Digital Stories Scoring Key" was used to collect quantitative data. In order to collect qualitative data, "Implementation Observation Form" and "Form for Determining Student Opinions Regarding Creating Digital Stories" were used.

\section{Creative thinking skill in digital stories scoring key}

A scoring key was developed by the researcher in order to determine the contribution of digital story creation to the creative thinking skills of middle school students. In this context, a literature review was made for story, digital story, creativity and creative thinking. A scoring key was created in line with the literature review and expert opinions. In order to determine the content validity and comprehensibility of the scoring key prepared, it was presented to the opinions of 16 field experts and three Turkish language teachers. It was edited in line with the feedback from experts, and a measurement tool consisting of seven dimensions and twenty eight sub dimensions was developed. In addition, Fleiss Kappa Statistics were used for the reliability study of the scoring key. When the values calculated for each item of the scoring key used in the analysis of 80 digital stories scored by three scorers are evaluated, it is found that there is moderate agreement in the dimensions of "Fluency, Imagination, Using Media Elements", and substantial agreement in the dimensions of "Originality, Analytical Thinking Skill, Different Perspective, Content".

\section{Implementation observation form}

The video recordings made during the digital story activities were examined by the researcher and the observation form developed by the researcher and three experts was filled. In the observation form, reflections are made on the activities taking place in the classroom and some inferences are made to develop a theme (Creswell, 2012). Using the observation form developed in this direction, the researcher examined the video records of the implementations and filled the observation form.

\section{Form for determining student opinions regarding creating digital stories}

The questions in the "Form for Determining the Student Opinions Regarding Creating Digital Story" were prepared as a result of the interview held with the researcher, the field expert and Turkish language teachers. Data were obtained as a result of semi structured interviews with students during the qualitative research process. 


\section{Data Collection}

\section{Preparation before implementation}

Interviews were made with the school administration, the Turkish language teacher and the information technology teacher of the middle schools that have an Information Technologies laboratory and students who have received coding education. In this direction, the school was selected and the necessary permissions were obtained. Necessary examinations have been made and the deficiencies have been corrected in the information technologies class where the application will be made. The information technologies class checked over and deficiencies addressed. A pilot implementation was carried out with the study group decided in line with the academic achievement score averages of the Turkish lesson and the information technologies lesson and the opinions of the branch teachers for four weeks.

In the pilot testing, first of all, the researcher employed icebreaker games with the study group. Then, she made a presentation about creativity, characteristics of creative individuals, story, elements of the story, digital story, elements of digital story, digital story creation stages. As an example, digital stories developed by the researcher and available at the address "https://scratch.mit.edu/" were shown to the students. The study group created digital storied using Scratch block coding on a topic they wanted. In the pilot testing, all the steps to be taken in the actual implementation have been done. The students brainstormed about the topic of the story. Then, the students first filled out the "Story Draft Form" and the "Digital Storyboard". Later, they filled out the "Digital Story Checklist" developed by the researcher.

\section{Implementation process}

In the framework of the seventh-grade Turkish textbook used in the research school, digital story activities related to the first four themes in the textbook were carried out with the study group. The activities carried out with the study group lasted 19 weeks. Students created each digital story individually using the Scratch block-based coding program.

\section{Conducting semi structured interviews}

Semi structured interviews were conducted with all students in the study group using the "Form for Determining the Student Opinions Regarding Creating Digital Story ".

\section{Observation}

While the digital story creation process was taking place, video recording was made for 19 weeks.

\section{Conducting retention test}

In order to test the permanence of the digital story activities for creative thinking skills, the retention test was conducted three weeks after the last implementation, that is to say the third theme. A digital story activity was conducted again with all students in the study group.

\section{Data Analysis}

SPSS package program was used in the analysis of quantitative data. Paired $t$ test results for each dimension in the scoring key were analyzed. In addition, $t$ test results were calculated for the total scores of the study group students obtained from each digital story they created.

Descriptive and content analysis were used in the analysis of qualitative data. The data obtained from the semi structured interviews with the students in the study group were analyzed by thematic coding. Descriptive analysis technique was used in giving direct views of the participants and interpreting the 
findings, and content analysis was used in the tabulation of the data under certain themes and categories. The video recordings made during the digital story creation process were examined one by one and these recordings were analyzed with the content analysis technique.

\section{Validity and Reliability}

There are some factors affecting internal validity in quantitative data. One of these factors is the "data collection tool" (Büyüköztürk, 2014). For the scoring key developed by the researcher, 16 field experts and three Turkish language teachers were consulted. In line with the feedback from experts, the measurement tool was edited and finalized. Digital stories created by the study group were evaluated by three experts with the measurement tool, and "Fleiss Kappa" interrater reliability analysis was used for the reliability study of the data obtained from the measurement tool. This contributed to the study in terms of both validity and reliability. Since the researcher carried out the implementation process from the beginning to the end and worked with a single study group, the effect of "practice" (Fraenkel et al., 2012) that threatened internal validity was not encountered. Purposeful sampling is used to provide external validity.

The data obtained from the forms used to ensure credibility in qualitative data were presented to the field expert. A long-term interaction lasting 19 weeks was carried out with the study group. Data diversification was ensured by interview and observation. The data collection tools, data collection process and analysis of the data and the process are explained in detail and transferability is ensured.

\section{FINDINGS}

In line with the data obtained in the study, the findings were explained by considering the sub problem order.

\section{Findings related to first sub problem: the contribution of the digital story creation process to creative thinking}

The data obtained from the study group within the scope of the first subproblem of the study, "Does digital story creation contribute to the creative thinking skills of middle school seventh grade students?", are presented in Tables 1 to 8 .

Table 1.

Paired t Test Results for Students' Fluency Scores

\begin{tabular}{llllllll}
\hline \multicolumn{1}{c}{ Variables } & $\mathrm{N}$ & $\overline{\mathrm{X}}$ & $\mathrm{SD}$ & $\mathrm{t}$ & $\mathrm{df}$ & $\mathrm{p}$ \\
\hline Pair 1 & Fluency. Theme 1 & 20 & 1,9984 &, 32624 & $-3,140$ & 19 & .005 \\
& Fluency. Theme 2 & 20 & 2,3368 &, 44792 & & & \\
Pair 2 & Fluency. Theme 1 & 20 & 1,9984 &, 32624 & $-7,932$ & 19 & .000 \\
& Fluency. Theme 3 & 20 & 2,7653 &, 27175 & & & \\
Pair 3 & Fluency. Theme 1 & 20 & 1,9984 &, 32624 & $-4,389$ & 19 & .000 \\
& Fluency. Theme 4 & 20 & 2,4510 &, 40424 & & & \\
Pair 4 & Fluency. Theme 2 & 20 & 2,3368 &, 44792 & $-4,297$ & 19 & .000 \\
& Fluency. Theme 3 & 20 & 2,7653 &, 27175 & & & \\
Pair 5 & Fluency. Theme 2 & 20 & 2,3368 &, 44792 &,- 961 & 19 & .349 \\
& Fluency. Theme 4 & 20 & 2,4510 &, 40424 & & & \\
Pair 6 & Fluency. Theme 3 & 20 & 2,7653 &, 27175 & 2,747 & 19 & .013 \\
& Fluency. Theme 4 & 20 & 2,4510 &, 40424 & & & \\
\hline
\end{tabular}

Table 1 shows the paired $t$ test results of the fluency scores obtained from the digital stories created by the students from the first implementation to the last. It was found that there was a significant increase between the students' first theme scores and second theme scores $(\mathrm{t}:-3,140, \mathrm{p}<.05)$, between first theme 
scores and third theme scores $(\mathrm{t}:-7.932 \mathrm{p}<.05)$, between first theme scores and fourth theme scores $(\mathrm{t}$ : $-4,389, \mathrm{p}<.05)$, between second theme scores and third theme scores ( $\mathrm{t}:-4.297, \mathrm{p}<.05)$, and between third theme scores and fourth theme scores $(\mathrm{t}: 2,747, \mathrm{p}<.05)$. While the average of the students' first theme fluency score was $\square: 1.99$, the average of third theme the last implementation fluency score rose to $\overline{\mathrm{x}}$ : 2.76. This finding shows that digital story creation activities contribute to students' creative thinking skills.

The $t$ test results of the students' scores of originality from the digital stories are presented in Table 2 .

Table 2.

Paired t Test Results for Students' Originality Scores

\begin{tabular}{llllllll}
\hline & Variables & $\mathrm{N}$ & $\overline{\mathrm{X}}$ & $\mathrm{SD}$ & $\mathrm{t}$ & $\mathrm{df}$ & $\mathrm{p}$ \\
\hline Pair 1 & Originality. Theme 1 & 20 & 1,4056 &, 30843 & $-4,630$ & 19 &, 000 \\
& Originality. Theme 2 & 20 & 1,9053 &, 43558 & & & \\
Pair 2 & Originality. Theme 1 & 20 & 1,4056 &, 30843 & $-9,128$ & 19 & \multirow{2}{*}{, 000} \\
& Originality. Theme 3 & 20 & 2,4085 &, 29113 & & & \\
Pair 3 & Originality. Theme 1 & 20 & 1,4056 &, 30843 & $-7,987$ & 19 & \multirow{2}{*}{, 000} \\
& Originality. Theme 4 & 20 & 2,2552 &, 27403 & & & \\
Pair 4 & Originality. Theme 2 & 20 & 1,9053 &, 43558 & $-4,819$ & 19 & \multirow{2}{*}{, 000} \\
& Originality. Theme 3 & 20 & 2,4085 &, 29113 & & & \\
Pair 5 & Originality. Theme 2 & 20 & 1,9053 &, 43558 & $-3,290$ & 19 & \multirow{2}{*}{, 004} \\
& Originality. Theme 4 & 20 & 2,2552 &, 27403 & & & \\
Pair 6 & Originality. Theme 3 & 20 & 2,4085 &, 29113 & 1,829 & 19 &, 083 \\
& Originality. Theme 4 & 20 & 2,2552 &, 27403 & & & \\
\hline
\end{tabular}

Table 2 shows the paired $t$ test results of the originality scores obtained from the digital stories created by the students from the first implementation to the last. It was found that there was a significant increase between first theme scores and second theme scores of the students $(t:-4,630, p<.05)$, between first theme scores and third theme scores $(\mathrm{t}:-9,128, \mathrm{p}<.05)$, between first theme scores and fourth theme scores ( $\mathrm{t}:-7,987, \mathrm{p}<.05)$, between second theme scores and third theme scores $(\mathrm{t}:-4,819, \mathrm{p}<.05)$, and between second theme scores and fourth theme scores (t: $-3,290, \mathrm{p}<.05)$. While the average of the students' first theme originality score was $\square: 1,40$, the average of third theme originality score rose to $\overline{\mathrm{x}}: 2.40$. This finding shows that digital story creation activities contribute to students' creative thinking skills. The $t$ test results of the students' scores of imagination from the digital stories are presented in Table 3.

Table 3.

Paired $t$ Test Results for Students' Imagination Scores

\begin{tabular}{|c|c|c|c|c|c|c|c|}
\hline \multirow{3}{*}{$\overline{\text { Pair } 1}$} & Variables & $\mathrm{N}$ & $\bar{X}$ & SD & $\mathrm{t}$ & $\mathrm{df}$ & $\mathrm{p}$ \\
\hline & Imagination. Theme 1 & 20 & 1,3485 & ,50099 &,- 785 & 19 & ,442 \\
\hline & Imagination. Theme 2 & 20 & 1,4815 & 60481 & & & \\
\hline \multirow[t]{2}{*}{ Pair 2} & Imagination. Theme 1 & 20 & 1,3485 & 50099, & $-5,016$ & 19 & ,000 \\
\hline & Imagination. Theme 3 & 20 & 2,3485 &, 55651 & & & \\
\hline \multirow[t]{2}{*}{ Pair 3} & Imagination. Theme 1 & 20 & 1,3485 & ,50099 & $-2,021$ & 19 & ,058 \\
\hline & Imagination. Theme 4 & 20 & 1,7655 &, 78734 & & & \\
\hline \multirow[t]{2}{*}{ Pair 4} & Imagination. Theme 2 & 20 & 1,4815 & 60481 & $-4,342$ & 19 & ,000 \\
\hline & Imagination. Theme 3 & 20 & 2,3485 &, 55651 & & & \\
\hline \multirow[t]{2}{*}{ Pair 5} & Imagination. Theme 2 & 20 & 1,4815 & 60481 & $-1,403$ & 19 & ,177 \\
\hline & Imagination. Theme 4 & 20 & 1,7655 & ,78734 & & & \\
\hline \multirow[t]{2}{*}{ Pair 6} & Imagination. Theme 3 & 20 & 2,3485 &, 55651 & 2,906 & 19 & ,009 \\
\hline & Imagination. Theme 4 & 20 & 1,7655 &, 78734 & & & \\
\hline
\end{tabular}

Table 3 shows the paired t test results of the imagination scores obtained from the digital stories created by the students from the first implementation to the last. It was found that there was a significant increase between the students' first theme scores and third theme scores $(\mathrm{t}:-5.016, \mathrm{p}<.05)$ and between second theme scores and third theme scores $(\mathrm{t}:-4.342, \mathrm{p}<.05)$. While the average of the students' first theme 
imagination score was $\overline{\mathrm{x}}: 1,34$, the average of third theme imagination score rose to $\overline{\mathrm{x}}: 2.34$. This finding shows that digital story creation activities contribute to students' creative thinking skills.

The $t$ test results of the students' scores of analytical thinking from the digital stories are presented in Table 4.

Table 4.

Paired $t$ Test Results for Students' Analytical Thinking Scores

\begin{tabular}{llllllll}
\hline \multicolumn{2}{c}{ Variables } & $\mathrm{N}$ & $\overline{\mathrm{X}}$ & $\mathrm{SD}$ & $\mathrm{t}$ & $\mathrm{df}$ & $\mathrm{p}$ \\
\hline Pair 1 & Analytical Thinking. Theme 1 & 20 & 1,6075 &, 51370 & $-1,389$ & 19 &, 181 \\
& Analytical Thinking. Theme 2 & 20 & 1,8397 &, 55973 & & & \\
Pair 2 & Analytical Thinking. Theme 1 & 20 & 1,6075 &, 51370 & $-6,170$ & 19 & \multirow{2}{*}{, 000} \\
& Analytical Thinking. Theme 3 & 20 & 2,5155 &, 45837 & & & \\
Pair 3 3 & Analytical Thinking. Theme 1 & 20 & 1,6075 &, 51370 & $-2,963$ & 19 & \multirow{2}{*}{, 008} \\
& Analytical Thinking. Theme 4 & 20 & 2,1307 &, 60832 & & & \\
Pair 4 4 & Analytical Thinking. Theme 2 & 20 & 1,8397 &, 55973 & $-4,188$ & 19 & \multirow{2}{*}{, 000} \\
& Analytical Thinking. Theme 3 & 20 & 2,5155 &, 45837 & & & \\
Pair 5 & Analytical Thinking. Theme 2 & 20 & 1,8397 &, 55973 & $-1,879$ & 19 & \multirow{2}{*}{, 076} \\
& Analytical Thinking. Theme 4 & 20 & 2,1307 &, 60832 & & & \\
Pair 6 6 & Analytical Thinking. Theme 3 & 20 & 2,5155 &, 45837 & 2,729 & 19 & \multirow{2}{*}{, 013} \\
& Analytical Thinking. Theme 4 & 20 & 2,1307 &, 60832 & & & \\
\hline
\end{tabular}

Table 4 shows the paired $t$ test results of the analytical thinking scores obtained from the digital stories created by the students from the first implementation to the last. It was found that there was a significant increase between the students' first theme scores and third theme scores ( $t:-6,170, p<.05)$, between first theme scores and fourth theme scores $(\mathrm{t}:-2.963, \mathrm{p}<.05)$, between second theme scores and third theme scores $(\mathrm{t}:-4,188, \mathrm{p}<.05)$ and between third theme scores and fourth theme scores $(\mathrm{t}: 2,729, \mathrm{p}<.05)$. While the average of the students' first theme analytical thinking score was $\bar{x}: 1,60$, the average of third theme analytical thinking score rose to $\bar{x}: 2.51$. This finding shows that digital story creation activities contribute to students' creative thinking skills. The t test results of the students' scores of diverse perspectives from the digital stories are presented in Table 5.

Table 5.

Paired t Test Results for Students' Diverse Perspectives Scores

\begin{tabular}{lllrrrrr}
\hline & \multicolumn{1}{c}{ Variables } & $\mathrm{N}$ & $\overline{\mathrm{X}}$ & $\mathrm{SD}$ & $\mathrm{t}$ & $\mathrm{df}$ & $\mathrm{p}$ \\
\hline Pair 1 & Diverse Perspectives. Theme 1 & 20 & 1,3075 &, 47184 &,- 414 & 19 &, 684 \\
& Diverse Perspectives. Theme 2 & 20 & 1,3572 &, 40478 & & & \\
Pair 2 & Diverse Perspectives. Theme 1 & 20 & 1,3075 &, 47184 & $-3,445$ & 19 &, 003 \\
& Diverse Perspectives. Theme 3 & 20 & 1,9317 &, 50493 & & & \\
Pair 3 3 & Diverse Perspectives. Theme 1 & 20 & 1,3075 &, 47184 &,- 786 & 19 &, 442 \\
& Diverse Perspectives. Theme 4 & 20 & 1,4488 &, 62071 & & & \\
Pair 4 4 & Diverse Perspectives. Theme 2 & 20 & 1,3572 &, 40478 & $-3,532$ & 19 &, 002 \\
& Diverse Perspectives. Theme 3 & 20 & 1,9317 &, 50493 & & & \\
Pair 5 & Diverse Perspectives. Theme 2 & 20 & 1,3572 &, 40478 &,- 566 & 19 & \multirow{2}{*}{, 578} \\
& Diverse Perspectives. Theme 4 & 20 & 1,4488 &, 62071 & & & \\
Pair 6 & Diverse Perspectives. Theme 3 & 20 & 1,9317 &, 50493 & 3,780 & 19 &, 001 \\
& Diverse Perspectives. Theme 4 & 20 & 1,4488 &, 62071 & & & \\
\hline
\end{tabular}

Table 5 shows the paired $t$ test results of the diverse perspectives scores obtained from the digital stories created by the students from the first implementation to the last. It was found that there was a significant increase between the students' first theme scores and third theme scores ( $\mathrm{t}:-3.445, \mathrm{p}<.05)$, between second theme scores and third theme scores $(\mathrm{t}:-3.532, \mathrm{p}<.05)$, and between third theme scores and fourth theme scores ( $\mathrm{t}: 3,780, \mathrm{p}<.05)$. While the average of the students' first theme diverse perspectives score was $\overline{\mathrm{x}}: 1,30$, the average of third theme diverse perspectives score rose to $\overline{\mathrm{x}}: 1,93$. This finding shows that digital story creation activities contribute to students' creative thinking skills. 
The $t$ test results of the students' scores of media elements from the digital stories are presented in Table 6.

Table 6.

Paired t Test Results for Students' Media Elements Scores

\begin{tabular}{llllllll}
\hline & Variables & $\mathrm{N}$ & $\overline{\mathrm{X}}$ & $\mathrm{SD}$ & $\mathrm{t}$ & $\mathrm{df}$ & $\mathrm{p}$ \\
\hline Pair 1 & Media Elements. Theme 1 & 20 & 2,0498 &, 23874 & $-2,968$ & 19 &, 008 \\
& Media Elements. Theme 2 & 20 & 2,3067 &, 46621 & & & \\
Pair 2 & Media Elements. Theme 1 & 20 & 2,0498 &, 23874 & $-8,760$ & 19 & \multirow{2}{*}{000} \\
& Media Elements. Theme 3 & 20 & 2,7234 &, 31398 & & & \\
Pair 3 & Media Elements. Theme 1 & 20 & 2,0498 &, 23874 & $-5,865$ & 19 & \multirow{2}{*}{000} \\
& Media Elements. Theme 4 & 20 & 2,5773 &, 30126 & & & \\
Pair 4 & Media Elements. Theme 2 & 20 & 2,3067 &, 46621 & $-3,849$ & 19 & \multirow{2}{*}{001} \\
& Media Elements. Theme 3 & 20 & 2,7234 &, 31398 & & & \\
Pair 5 & Media Elements. Theme 2 & 20 & 2,3067 &, 46621 & $-2,708$ & 19 & \multirow{2}{*}{, 014} \\
& Media Elements. Theme 4 & 20 & 2,5773 &, 30126 & & & \multirow{2}{*}{ Pair 6 } \\
& Media Elements. Theme 3 & 20 & 2,7234 &, 31398 & 1,395 & 19 &, 179 \\
& Media Elements. Theme 4 & 20 & 2,5773 &, 30126 & & & \\
\hline
\end{tabular}

Table 6 shows the paired $t$ test results of the media elements scores obtained from the digital stories created by the students from the first implementation to the last. It was found that there was a significant increase between the students' first theme scores and third theme scores $(\mathrm{t}:-8,760, \mathrm{p}<.05)$, between first theme scores and fourth theme scores $(\mathrm{t}:-5,865, \mathrm{p}<.05)$ and between second theme scores and third theme scores $(\mathrm{t}:-3,849, \mathrm{p}<.05)$. While the average of the students' first theme media elements score was $\overline{\mathrm{x}}: 2,04$, the average of third theme media elements score rose to $\overline{\mathrm{x}}: 2,72$. This finding shows that digital story creation activities contribute to students' creative thinking skills. The t test results of the students' scores of digital story content from the digital stories are presented in Table 7.

Table 7.

Paired t Test Results for Students' Digital Story Content Scores

\begin{tabular}{llllllll}
\hline & Variables & $\mathrm{N}$ & $\overline{\mathrm{X}}$ & $\mathrm{SD}$ & $\mathrm{t}$ & $\mathrm{df}$ & $\mathrm{p}$ \\
\hline Pair 1 & Content. Theme 1 & 20 & 1,3758 &, 40408 & $-1,753$ & 19 &, 096 \\
& Content. Theme 2 & 20 & 1,6284 &, 54633 & & & \\
Pair 2 & Content. Theme 1 & 20 & 1,3758 &, 40408 & $-4,811$ & 19 &, 000 \\
& Content. Theme 3 & 20 & 2,2051 &, 52482 & & & \\
Pair 3 & Content. Theme 1 & 20 & 1,3758 &, 40408 & $-2,881$ & 19 &, 010 \\
& Content. Theme 4 & 20 & 1,8958 &, 70747 & & & \\
Pair 4 & Content. Theme 2 & 20 & 1,6284 &, 54633 & $-3,674$ & 19 &, 002 \\
& Content. Theme 3 & 20 & 2,2051 &, 52482 & & & \\
Pair 5 & Content. Theme 2 & 20 & 1,6284 &, 54633 & $-1,457$ & 19 &, 161 \\
& Content. Theme 4 & 20 & 1,8958 &, 70747 & & & \\
Pair 6 & Content. Theme 3 & 20 & 2,2051 &, 52482 & 1,453 & 19 &, 162 \\
& Content. Theme 4 & 20 & 1,8958 &, 70747 & & & \\
\hline
\end{tabular}

Table 7 shows the paired $t$ test results of content scores obtained from the digital stories created by the students from the first implementation to the last. It was found that there was a significant increase between the students' first theme scores and third theme scores $(\mathrm{t}:-4,811, \mathrm{p}<.05)$, between first theme scores and fourth theme scores ( $\mathrm{t}:-2,881, \mathrm{p}<.05)$, and between second theme scores and third theme scores ( $\mathrm{t}:-3,674, \mathrm{p}<.05)$. While the average of the students' first theme content score was $\overline{\mathrm{x}}: 1,37$, the average of third theme content score rose to $\overline{\mathrm{x}}: 2,20$. This finding shows that digital story creation activities contribute to students' creative thinking skills.

The $t$ test results of the students' total scores obtained from each digital story they created are presented in Table 8. 
Table 8.

Paired t Test Results for Students' Creative Thinking Skills Scores

\begin{tabular}{llllllll}
\hline \multicolumn{2}{c}{ Variables } & $\mathrm{N}$ & $\overline{\mathrm{X}}$ & $\mathrm{SD}$ & $\mathrm{T}$ & $\mathrm{df}$ & $\mathrm{p}$ \\
\hline Pair 1 & Creative Thinking. Theme 1 & 20 & 1,5847 &, 28905 & $-2,625$ & 19 &, 017 \\
& Creative Thinking. Theme 2 & 20 & 1,8365 &, 41594 & & & \\
Pair 2 & Creative Thinking. Theme 1 & 20 & 1,5847 &, 28905 & $-7,603$ & 19 &, 000 \\
& Creative Thinking. Theme 3 & 20 & 2,4140 &, 30461 & & & \\
Pair 3 3 & Creative Thinking. Theme 1 & 20 & 1,5847 &, 28905 & $-4,302$ & 19 &, 000 \\
& Creative Thinking. Theme 4 & 20 & 2,0749 &, 43832 & & & \\
Pair 4 & Creative Thinking. Theme 2 & 20 & 1,8365 &, 41594 & $-5,220$ & 19 &, 000 \\
& Creative Thinking. Theme 3 & 20 & 2,4140 &, 30461 & & & \\
Pair 5 & Creative Thinking. Theme 2 & 20 & 1,8365 &, 41594 & $-2,039$ & 19 &, 056 \\
& Creative Thinking. Theme 4 & 20 & 2,0749 &, 43832 & & & \\
Pair 6 & Creative Thinking. Theme 3 & 20 & 2,4140 &, 30461 & 3,212 & 19 &, 005 \\
& Creative Thinking. Theme 4 & 20 & 2,0749 &, 43832 & & & \\
\hline
\end{tabular}

Table 8 shows the paired $t$ test results of the students' first theme, second theme, third theme and fourth theme permanence test scores. According to the results, it was found that there was an increase between the students' first theme and second theme scores $(\mathrm{t}:-2,625, \mathrm{p}<.05)$, between first theme and third theme scores $(\mathrm{t}:-7,603, \mathrm{p}<.05)$, between first theme and permanence test scores $(\mathrm{t}:-4,302, \mathrm{p}<.05)$, between second theme and third theme scores $(\mathrm{t}:-5,220, \mathrm{p}<.05)$ and between third theme and permanence test scores (t: 3,212, p <.05). While the average of the students' first theme creative thinking skills score was $\square: 1,58$, the average of third theme creative thinking skills score rose to $\square: 2,41$. According to these findings, it is seen that the creative thinking skill scores of the students increased in a statistically significant way. It shows that digital story creation activities contribute to the creative thinking skills of students.

Findings related to second sub problem: permanence test results on creative thinking skills of digital story creation process

Three weeks after third theme implementation with the study group, the digital story creation process was carried out on fourth theme.

The data obtained from the study group within the scope of the second subproblem of the study, "Do digital story creation activities ensure that creative thinking skills are permanent?", are presented below.

Table 9.

Paired t Test Results for Students' Permanence Test Scores

\begin{tabular}{llllllll}
\hline \multicolumn{2}{c}{ Variables } & $\mathrm{N}$ & $\overline{\mathrm{X}}$ & $\mathrm{SD}$ & $\mathrm{t}$ & $\mathrm{df}$ & $\mathrm{p}$ \\
\hline Pair 1 & Creative Thinking. Theme 3 & 20 & 2,4140 &, 30461 & 3,212 & 19 & 0,05 \\
& Creative Thinking. Theme 4 & 20 & 2,0749 &, 43832 & & & \\
\hline
\end{tabular}

In Table 9, paired $t$ test results are given in order to test whether there is a significant difference between the permanence test scores of the study group. Accordingly, it was found that there was a significant difference between third theme score average of the study group $(\overline{\mathrm{x}}=2.41)$ and the permanence test mean score $(\overline{\mathrm{x}}=2.07)(\mathrm{t}: 3,212, \mathrm{p}<.05)$. It was seen that the average of the scores of the study group in the third implementation was higher than the average of the scores obtained in the fourth implementation.

\section{Findings related to third sub problem: students' views on digital story creation activities}

Data regarding the opinions of the study group on creating digital stories were presented. The general evaluations of the students about digital story creation activities are shown in Table 10. 


\section{Table 10.}

Views on Digital Story Creation Activities

\begin{tabular}{lll}
\hline Categories & $\mathrm{f}$ & $\%$ \\
\hline Enjoyable & 17 & 85 \\
Improving both story writing and coding ability & 4 & 20 \\
Developing the imagination & 4 & 20 \\
Providing personal development & 4 & 20 \\
Difficulty in coding & 2 & 10 \\
Boring & 2 & 10 \\
\hline
\end{tabular}

According to Table 10, it was seen that $85 \%$ of the students found the digital story creation activities entertaining and most of them expressed a positive opinion. $10 \%$ of the students stated negative opinions about digital story activities because they had difficulty in coding and $10 \%$ found the activities boring.

Some of the views expressed by the students are as follows:

I'm having so much fun. I am improving myself in writing stories. (S3).

Writing stories is nice, but coding is boring because I don't like using computers. (S8).

The opinions of the students on the preparations before creating the digital story are shown in Table 11 .

Table 11.

Views on Preparations before Digital Story Creation

\begin{tabular}{llll}
\hline Subcategories & Categories & f & $\%$ \\
\hline Brainstorming & Providing thinking & 7 & 35 \\
& Enjoyable & 3 & 15 \\
& Making writing easier & 3 & 15 \\
\cline { 2 - 3 } Story draft & Useful & 6 & 30 \\
& Making creating digital story easier & 5 & 25 \\
& Providing thinking & 3 & 15 \\
& Enjoyable & 2 & 10 \\
& Boring & 1 & 5 \\
\cline { 2 - 4 } Storyboard & Making creating digital story easier & 5 & 25 \\
& Ensuring planned work & 3 & 15 \\
& Difficult & 3 & 15 \\
& Boring & 2 & 10 \\
\cline { 2 - 4 } Checklist & Providing information about the story & 6 & 30 \\
& Nice & 3 & 15 \\
& A tool for self evaluation & 3 & 15 \\
& Unnecessary & 3 & 15 \\
\hline
\end{tabular}

According to Table 11,35\% of the students stated that the brainstorming technique enabled thinking. Most of the students (80\%) expressed a positive opinion about the brainstorming technique. Under the story draft subcategory, the most of the students' opinions were gathered in the category of finding useful $(35 \%)$. While students stated their positive opinions under the categories such as "Making creating digital story easier (25\%)", "Providing thinking (15\%)" and "Enjoyable (10\%)", they stated their negative opinions under the category "Boring (5\%)". When the storyboard subcategory was examined, students' opinions were gathered under the categories of "Making creating digital story easier (25\%)", "Ensuring planned work (15\%)", "Difficult (15\%)" and "Boring (15\%)". In the subcategory of the checklist, students' views are gathered under the categories of "Providing information about the story (30\%)", "Nice (15\%)", "A tool for self evaluation (15\%)" and "Unnecessary (15\%)" .

Some of the views expressed by the students are as follows:

I can write stories more easily thanks to brainstorming (S2). 
Draft story writing is a bit boring and tiring (S14).

The storyboard was good as it made it easier for me to finish my digital story (S10).

The digital story checklist explains what we do with the story so I think it's very good (Ö5).

Students' views on digital stories and creative thinking are shown in Table 12.

Table 12.

Views on Digital Stories and Creative Thinking

\begin{tabular}{|c|c|c|c|}
\hline Subcategories & Categories & $\mathrm{f}$ & $\%$ \\
\hline \multirow[t]{5}{*}{ Diverse perspective } & Providing thinking & 5 & 25 \\
\hline & Providing diverse thinking & 3 & 15 \\
\hline & Improving imagination & 3 & 15 \\
\hline & Educative & 2 & 10 \\
\hline & A tool for self expression & 1 & 5 \\
\hline \multirow[t]{4}{*}{ Analytical thinking } & Making connections between story elements & 5 & 25 \\
\hline & Improving story writing & 4 & 20 \\
\hline & Making writing easier & 2 & 10 \\
\hline & Useful in story building & 1 & 5 \\
\hline \multirow[t]{4}{*}{ Fluency } & Improving vocabulary & 10 & 50 \\
\hline & Improving story writing & 2 & 10 \\
\hline & Making meaningful sentences & 1 & 5 \\
\hline & Using words correctly & 1 & 5 \\
\hline \multirow[t]{4}{*}{ Imagination } & Improving imagination & 7 & 35 \\
\hline & Making thinking easier & 3 & 15 \\
\hline & Making writing easier & 2 & 10 \\
\hline & Providing versatile thinking & 1 & 5 \\
\hline \multirow[t]{3}{*}{ Originality } & Writing on your own & 6 & 30 \\
\hline & Improving story writing & 3 & 15 \\
\hline & Providing fluent thinking & 2 & 10 \\
\hline \multirow[t]{5}{*}{ Multimedia } & Creating good stories & 3 & 15 \\
\hline & Making writing easier & 2 & 10 \\
\hline & Enriching the expression & 2 & 10 \\
\hline & Making story clearer & 2 & 10 \\
\hline & Visualization & 1 & 5 \\
\hline Content & Enabling to identify the elements of the story & 4 & 20 \\
\hline
\end{tabular}

According to Table 12, 25\% of the students in "Diverse perspective" subcategory stated that digital story creation activities enabled thinking. In addition, it was stated by the students that digital story creation activities enabled diverse thinking (25\%) and improved imagination $(25 \%)$. In the subcategory of "Analytical thinking", $25 \%$ of the students stated that they could easily make connections between story elements thanks to digital story creation activities. In addition, the students stated that they wrote better stories (20\%) and that it became easier (10\%). In the subtheme of "Fluency", it was stated by 50\% of the students that their vocabulary developed thanks to digital story creation activities. Under the "Imagination" subcategory, 35\% of the students stated that digital story creation activities developed their imagination. "Providing thinking (15\%)" and "Making writing easier (10\%)" are the other opinions expressed by the students. In the subcategory of "Originality", $30 \%$ of the students stated that they could write their own unique stories thanks to digital story creation activities. They also stated that this way, they could write better stories (15\%) and think fluently (10\%). In the "Multimedia" subcategory, 15\% of the students stated that the media elements make the story nice. In addition, "Making writing easier $(10 \%) "$ ", "Enriching the expression (10\%)" and "Making story clearer (10\%)" are the other categories. Finally, it was stated that digital story creation activities under the "Content" subcategory enabled and facilitated $(20 \%)$ to identify the elements of the story.

Some of the views expressed by the students are as follows: 
Digital story creation activities help me explain myself and develop my imagination (S16).

Digital story creation activities helped me make sentences more meaningful (S1).

Thanks to digital story creation activities, I think more diverse. (S12).

Thanks to digital story creation activities, I generate more ideas as I write stories (S7).

Digital story creation activities are visually better (S8).

The opinions of the students about the contribution of digital story creation activities to Turkish lessons are presented in Table 13.

Table 13.

The Contribution of Digital Story Creation Activities to Turkish Lesson

\begin{tabular}{llll}
\hline Subcategories & Categories & $\mathrm{f}$ & $\%$ \\
\hline Creativity & Improving imagination & 6 & 30 \\
& Improving creative thinking & 3 & 15 \\
Making writing easier & Feeling creative & 2 & 10 \\
\cline { 2 - 4 } & Improving writing & 5 & 25 \\
& Making writing easier & 3 & 15 \\
Enjoying writing & Improving vocabulary & 2 & 10 \\
& Providing thinking & 2 & 10 \\
\cline { 2 - 4 } Success & Willingness to write & 7 & 35 \\
& Enjoyable & 3 & 15 \\
\cline { 2 - 4 } & Developing thinking skills & 2 & 10 \\
Development of language skills & Increasing interest towards lesson & 2 & 10 \\
& Feeling more successful & 2 & 10 \\
\cline { 2 - 4 } Interest towards lesson & Improving vocabulary & 1 & 5 \\
\cline { 2 - 4 } & Improving writing & 5 & 25 \\
& Providing personal development & 2 & 10 \\
\cline { 2 - 4 } & Increasing interest towards lesson & 6 & 30 \\
\hline
\end{tabular}

When Table 13 is examined, it was seen that $30 \%$ of the students stated that their imagination would develop with digital story creation activities in Turkish lessons in the subcategory "Creativity". In addition, the categories of "Improving creative thinking (15\%)" and "Feeling creative (10\%)" are other important findings. When the opinions of the students were examined in the subcategory "Making writing easier", it was observed that $25 \%$ of them stated that their writing skills would improve with digital story creation activities in Turkish lessons. In addition, students thought that they would improve in terms of writing stories more easily $(15 \%)$, improving vocabulary $(10 \%)$ and providing thinking $(10 \%)$. In the subcategory of "Enjoying writing", the opinions of the students were combined under the category of "Willingness to write (35\%)". In addition, it was stated by the students that digital story creation activities would make Turkish lessons fun (10\%). In the subcategory of "Success", "Developing thinking skills (10\%)", "Increasing interest towards lesson (10\%)", "Feeling more successful (10\%)" are important findings. Under the "Development of language skills" subcategory, most of the views of the students were gathered in the "Improving vocabulary (25\%)" category. In addition, it was stated that digital story creation activities to be carried out by students in Turkish lessons will improve writing $(10 \%)$ and provide personal development (10\%). Finally, in the subcategory of "Interest towards lesson", students stated that digital story creation activities would increase their interest in Turkish lesson. Two students who thought that digital story making activities would not be useful in Turkish lessons stated that their Turkish teachers did not want such a thing from them.

Some of the views expressed by the students are as follows: 
I think digital story making activities will be useful in Turkish lessons because it broadens my imagination (S16).

I think digital story creation activities will be useful in Turkish lessons because I write more comfortably (S14).

I think digital story creation activities will be useful in Turkish lessons because it is fun (S18).

I think digital story creation activities will be useful in Turkish lessons because it constantly improves writing (S11).

\section{Findings related to fourth sub problem: digital story creation process observation results}

The results of the observations made during the weeks of the implementation are presented below. The arithmetic mean results of the social environment of the study group students during the IMP (implementation) are shown in Table 14.

Table 14.

Digital Story Creation Process Social Environment Observation Results

\begin{tabular}{|c|c|c|c|c|c|}
\hline Dimensions & Sub Criteria & 1. IMP & 2. IMP & 3. IMP & 4. IMP \\
\hline \multirow[t]{4}{*}{ Social Environment } & There was communication between students. & 2,00 & 3,00 & 3,00 & 4,00 \\
\hline & There was communication with the researcher. & 5,00 & 5,00 & 5,00 & 5,00 \\
\hline & Students asked each other about the activity. & 5,00 & 4,50 & 3,00 & 2,25 \\
\hline & $\begin{array}{l}\text { The students asked the researcher about the } \\
\text { activity. }\end{array}$ & 5,00 & 5,00 & 3,50 & 2,25 \\
\hline
\end{tabular}

According to Table 14, it is seen that as the weeks progressed, sub criteria related to communication increased, and sub criteria related to asking questions decreased.

Table 15.

Digital Story Creation Implementation Process Observation Results

\begin{tabular}{|c|c|c|c|c|c|}
\hline Dimensions & Sub Criteria & 1. IMP & 2. IMP & 3. IMP & 4. IMP \\
\hline \multirow[t]{8}{*}{$\begin{array}{l}\text { Implementation } \\
\text { Process }\end{array}$} & $\begin{array}{l}\text { The students actively participated in the } \\
\text { activity. }\end{array}$ & 3,00 & 4,25 & 5,00 & 4,50 \\
\hline & $\begin{array}{l}\text { They actively participated in the } \\
\text { brainstorming activity. }\end{array}$ & 4,00 & 5,00 & 5,00 & 5,00 \\
\hline & $\begin{array}{l}\text { They actively participated in the draft story } \\
\text { writing process. }\end{array}$ & 3,00 & 4,00 & 4,00 & 4,00 \\
\hline & They were willing to create storyboards. & 2,00 & 2,00 & 3,00 & 3,00 \\
\hline & $\begin{array}{l}\text { They were willing to fill out the digital story } \\
\text { checklist. }\end{array}$ & 3,00 & 3,00 & 4,00 & 5,00 \\
\hline & $\begin{array}{l}\text { They were keen to reach out to media } \\
\text { elements. }\end{array}$ & 4,00 & 4,25 & 5,00 & 5,00 \\
\hline & $\begin{array}{l}\text { They had problems using the coding program } \\
\text { to create stories. }\end{array}$ & 5,00 & 3,00 & 2,25 & 2,00 \\
\hline & $\begin{array}{l}\text { They came up with many different ideas and } \\
\text { solutions to create a story. }\end{array}$ & 2,00 & 2,25 & 3,75 & 3,00 \\
\hline
\end{tabular}

It was observed that the active participation of the study group in the digital story creation process increased as the weeks progressed. It is seen that the participation in the brainstorming activity is high since the first implementation. It was observed that students had problems with creating the draft story writing in the first implementation. When the arithmetic means of the sub criteria related to the desire to create a storyboard are examined, it is seen that students rarely perform this behavior. The arithmetic means of the sub criteria for filling out the digital story checklist increased as the weeks progressed. The 
study group has been keen to reach out to the media elements since the beginning of the implementation process. Although the study group consisted of students who previously studied Scratch, it was observed that the students had problems using the Scratch program to create a story. Most of the questions asked to the researcher, especially at the beginning of the implementation process, were about this problem. However, as the weeks progressed, it was observed that the problems experienced decreased. When the arithmetic means of the sub criteria related to producing many different ideas and solutions for story creation are examined, it is seen that students rarely perform this behavior in the first two implementations.

Table 16.

Digital Story Creation Verbal and Nonverbal Communication Process Observation Results

\begin{tabular}{|c|c|c|c|c|c|}
\hline Dimensions & Sub Criteria & 1. IMP & 2. IMP & 3. IMP & 4. IMP \\
\hline $\begin{array}{l}\text { Verbal and } \\
\text { Nonverbal } \\
\text { Communication }\end{array}$ & $\begin{array}{l}\text { The students used expressions stating } \\
\text { that they liked the implementation } \\
\text { process. }\end{array}$ & 2,00 & 2,75 & 3,75 & 3,50 \\
\hline Process & $\begin{array}{l}\text { The students' mimics and gestures } \\
\text { showed that they liked the } \\
\text { implementation process. }\end{array}$ & 2,00 & 2,75 & 3,75 & 3,50 \\
\hline
\end{tabular}

As the weeks progressed, there was an increase in behavior. It was observed that the arithmetic mean of the study group regarding the verbal and nonverbal communication process dimension was low in the first implementations, but there was an increase in this dimension in the last two implementations.

\section{DISCUSSION, CONCLUSION, AND SUGGESTIONS}

Within the framework of the main purpose of this study, the contribution of creating digital stories to the creative thinking skills of middle school seventh grade students was determined. When the paired $t$ test results obtained from the digital story scores of the study group were analyzed as a whole, it was observed that there was a significant increase in the scores of the students.

It was found that there was a significant increase in the scores of the digital stories created by the study group students in "fluency", "originality", "imagination", "analytical thinking skill", "different perspective", "media elements" and "content" dimensions. According to these results, it is seen that the digital story creation skill has a significant effect on creative thinking. Similarly, Vinogradova et al. (2011) stated that students developed fluency in written and spoken languages as a result of the digital story implementations they made with students of a language center. In their research Del Moral et al. (2019) developed stories with primary school students using various digital story creation applications. According to the results of their research, it was stated that digital story applications support originality. Burke and Kafai (2010) stated that as a result of their studies with middle school students, they created fictions with creative and aesthetic features using their imaginations through Scratch programming. Hung et al. (2012) found that project based learning with digital stories increased the problem solving skills of experimental group students in their research by forming an experiment and control group with 117 students studying in fifth grade. In the research conducted by Liu et al. (2010) digital stories were created by students in a collaborative environment using the methods stated as linear and nonlinear. In the study, in which 57 students in the third grade participated, it was stated that the students created stories with a more flexible and different perspective with the nonlinear method. Yamaç (2015), in his doctoral thesis with third grade primary school students, stated that creating digital stories made up of different media elements increased students' desire to participate in implementations and thus their motivation increased. In the study conducted by Lim and Noor (2019) with secondary school students, the digital stories developed by students were evaluated using a scoring key. One dimension included in the scoring key used was named "Quality of the visuals" and in this dimension, students were expected to use different and appropriate visuals that match the parts of the story. Accordingly, it was stated that 
there was a significant difference between the scores of the students in the quality of the visuals as a result of the evaluation.

When the total scores of the study group obtained from digital stories were examined, it was observed that the digital story creation activities contributed to the creative thinking skills of the students. Jenkins and Lonsdale (2007), Wu and Yang (2008), Coutinho (2010), Motsamai (2012), LaFrance and Blizzard (2013), Fields et al. (2014), Karakoyun (2014), Thorne (2014), Yavuz Konokman (2015), Akyeampong (2018), Karakuş et al. (2020), Yang et al. (2020) also found a positive relationship between digital story creation and creative thinking in these studies. What is different from the majority of the previous studies is that the way to create a story through programming can develop creative thinking.

Another important result of the study is that there is a significant difference between the permanence test scores of the students. Similarly, in the study conducted by Aktaş and Yurt (2017), the effect of digital story creation on academic achievement, learning motivation and permanence was investigated and it was stated that permanent learning was achieved according to the results obtained from the permanence test.

When the opinions of the students on the digital story making activities were examined, it was seen that they found the digital story making activities entertaining and most of them expressed positive opinions. A similar result was obtained in the study of Aydın (2019) aiming to examine the effect of digital storytelling on the development of creative writing skills of students who learn Turkish as a foreign language. Most of the students stated that creating a digital story is an entertaining activity. When the opinions of the students on the preparations before the digital story creation were examined, it was seen that the majority expressed positive opinions on the brainstorming technique, story draft and checklist. While the students stated that the storyboard made it easier to create digital stories, they also expressed their negative opinions by finding it difficult and boring to create a storyboard. There are similar research results in the literature. Ulum and Ercan Yalman (2020) stated that students expressed positive opinions in the writing stage, which is one of the stages of creating digital stories, as a result of their interviews with students in their study, which aimed to determine the digital story creation experiences of seventh grade students in the science course, and that students had fun in this process. Burke and Kafai (2012) stated in their study in which they researched the process of middle school students' preparing, reviewing and publishing their digital stories using Scratch programming that students created a resistance to filling the storyboard, and they were very reluctant to return to pen and paper after computer use. When the students' views on the theme of creative thinking were examined, most of them stated that digital story creation activities provided them different perspectives, analytical thinking skills and word fluency, improved imagination and writing, multimedia features made it easier to write stories and enriched the narration, and they could realize the elements of the story more easily thanks to digital story activities. There are many studies in the literature that indicate that creative and critical thinking skills can be developed with digital stories (Abdel-Hack \& Helwa, 2014; Ohler, 2008; Czarnecki, 2009; Yüksel et al., 2011; Yang \& Wu, 2012; Erişti-Bedir, 2014; Niemi et al., 2014; Hagge, 2017; Akyeampong, 2018; Kim \& Lee, 2018; Vinayakumar et al., 2018; Al Khateeb, 2019; Chan, 2019; Moradi \& Chen, 2019; Yang et al., 2020). When the opinions about the contribution of digital story creation activities to Turkish lesson were examined, it was observed that the majority of the students stated that digital story creation activities would be beneficial in Turkish lessons. It was observed that the views were concentrated especially on the development of creativity, writing easier and liking to write. In his doctoral thesis, Baki (2015) investigated the effects of digital stories on students' story writing skills, writing anxiety, writing self efficacy and attitudes towards writing in the sixth grade Turkish course. Similar to the finding obtained in our study, the opinions of the study group students who carried out digital story activities showed that they were more interested in writing. The views of the students about digital stories and the implementation process such as "enjoyable, improving both story writing and coding ability, developing the imagination, the positive effect on the thinking process, increasing interest towards writing" support the increase in the average scores of the students from the digital stories they create. 
According to the results obtained from the observations, it was seen that the students were in communication with the researcher and his friends by asking questions and exchanging ideas during the implementation. It was observed that the behavior of students asking questions about activities decreased week by week. It was observed that the study group students participated in the activities more actively as the activities progressed, and they had less problems in using the Scratch coding program to create digital stories. In addition, it was found that as the implementation process progressed, they used analytical thinking and problem solving skills more actively. Similarly, students' expressions of verbal and nonverbal communication increased week by week. The observation findings which show the increase in behaviors such as willingness to reach media elements, to create digital stories and to participate in the implementation process support the increase in the scores obtained from digital stories. The increase in the expressions, gestures and facial expressions of the students showing that they enjoyed the activities from the second implementation onwards are behaviors that are compatible with the increase in the scores obtained from the digital stories. These results are consistent with the research results in the literature (Smeda et al., 2014; Tatlı \& Aksoy, 2017). In their study, Tatl1 and Aksoy (2017) aimed to investigate the effect of the digital story method in the speaking class of students studying in the foreign language preparatory class. The students prepared digital stories and the process was observed by the researchers. According to the observation findings, it was stated that the students enjoyed the application, participated actively in the implementation, but had problems in using the program. Smeda et al., (2014) stated in their study, which aimed to increase student participation and learning with the digital story method, according to the observation results, students helped each other in technical matters, cooperation was observed between groups and communication between them increased.

As a result of this research, it was concluded that digital storytelling contributes to creative thinking skills. In this context, it is thought that the traditional writing process can be developed by transferring it to today's technology environment and students will be active learners in an environment where they can improve their academic performance, higher order thinking skills, learning motivation and learning behaviors. Thus, it is possible to make the following recommendations:

1. Since it is thought that creative thinking skill with digital story method through coding will be effective at other grade levels and lessons, it will be useful to try it in various education levels and lessons.

2. Creative thinking skills of students will be developed with the practical activities for the digital story method to be prepared in student textbooks.

3. Although the acquisition of metacognitive skills and digital competence are considered important in the Turkish course curriculum, it is seen that the digital story method is not included in the content of the program. Making the necessary arrangements in this regard is considered important in terms of acquiring metacognitive skills.

4. Teachers who are practitioners in classrooms should be informed about new approaches through in service training, and teacher candidates in education faculties should also be trained on this subject.

\section{Acknowledgement}

This article is derived from Nesime Ertan Özen's PhD dissertation entitled "Contribution of Digital Storytelling to $7^{\text {th }}$ Grade Students' Creative Thinking Skills", conducted under the supervision of Prof. Dr. Erol Duran.

\section{REFERENCES}

Abdel Hackl, E. M., \& Helwa, H. S. (2014). Using digital storytelling and weblogs instruction to enhance EFL narrative writing and critical thinking skills among EFL majors at faculty of education. Educational Research, 5(1), 8-41. 
Aktaş, E., \& Yurt, S. U. (2017). Effects of digital story on academic achievement, learning motivation and retention among university students. International Journal of Higher Education, 6(1), 180-196. http://dx.doi.org/10.5430/ijhe.v6n1p180

Akyeampong, A. S. (2018). Promoting creativity and critical thinking through digital storytelling: Perceptions of undergraduate students. In B. Hokanson, G. Clinton, \& K. Kaminski (Eds), Educational technology and narrative (pp. 271-282). Springer.

Al Khateeb, A. A. (2019). Socially orientated digital storytelling among Saudi EFL learners. Interactive Technology and Smart Education, 16(2), 130-142. https://doi.org/10.1108/ITSE-11-2018-0098

Aydın, E. (2019). The effect of digital storytelling on creative writing skills in teaching Turkish to foreigners. (Unpublished doctoral dissertation). İnönü University.

Baki, Y. (2015). The effect of digital stories on the sixth grade students' writing process. (Unpublished doctoral dissertation). Atatürk University.

Balanskat, A., \& Engelhardt, K. (2015). Computing our future: Computer programming and coding - Priorities, school curricula and initiatives across Europe. European Schoolnet.

Balc1, A. (2013). Sosyal bilimlerde araştırma [Research in social sciences]. Pegem.

Barrett, H. (2006). Researching and evaluating digital storytelling as a deep learning tool. In C. Crawford, et al. (Eds.), Proceedings of Society for Information Technology and Teacher Education International Conference 2006 (pp. 647-654). VA: AACE.

Baz, F. Ç. (2018). A comparative analysis of coding software for children. Current Research in Education, 4(1), 36-47.

Burke, Q. (2012). The markings of a new pencil: Introducing programming-as writing in the middle school classroom. Journal of Media Literacy Education, 4(2), 121-135.

Burke, Q., \& Kafai, Y. B. (2010, June). Programming \& storytelling: opportunities for learning about coding \& composition. Proceedings of the 9th International Conference on Interaction Design and Children.

Burke, Q., \& Kafai, Y. B. (2012, February). The writers' workshop for youth programmers: digital storytelling with scratch in middle school classrooms. Proceedings of the 43rd ACM technical symposium on Computer Science Education.

Büyüköztürk, Ş. (2014). Deneysel desenler ön test-son test kontrol grubu desen ve veri analizi [Experimental designs pretest-posttest control group design and data analysis]. Pegem.

Chan, C. (2019). Using digital storytelling to facilitate critical thinking disposition in youth civic engagement: A randomized control trial. Children and Youth Services Review, 107, 1-10. https://doi.org/10.1016/j.childyouth.2019.104522

Coutinho, C. (2010). Storytelling as a strategy for integrating technologies into the curriculum: empirical study with post-graduate teachers. https://core.ac.uk/download/pdf/55611234.pdf

Creswell, J. W. (2012). Educational research: planning, conducting, and evaluating quantitative and qualitative research. Pearson Education.

Creswell, J. W., Clark, P. V. L., Gutmann, M. L., \& Hanson, W. E. (2003). An expanded typology for classifying mixed methods research into designs. In A. Tashakkori \& C. Teddlie (Eds.) Handbook of mixed methods in social and behavioral research (pp. 209-240). Sage.

Creswell, J. W., \& Clark, P. V. L. (2007). Designing and conducting mixed methods research. Sage.

Czarnecki, K. (2009). How digital storytelling builds 21st century skills. Library technology reports, 45(7), 1519.

Del Moral, M. E., Bellver Moreno, M. C., \& Guzmán-Duque, A. P. (2019). Evaluating the creative potencial of digital storytelling APPs for Primary Education. Ocnos Revista de Estudios Sobre Lectura, 18(1), 7-20. https://doi.org/10.18239/ocnos_2019.18.1.1866

Doğan, B. (2007). Implementation of digital storytelling in the classroom by teachers trained in a digital storytelling workshop (Unpublished doctoral dissertation). ProQuest Digital Dissertations (UMI 3272583).

Dorner, R., Grimm, P., \& Abawi, D. F. (2002). Synergies between interactive training simulations and digital storytelling: a component-based framework. Computers \& Graphics, 26(1), 45-55. https://doi.org/10.1016/S0097-8493(01)00177-7

Duran, E., \& Ertan Özen, N. (2018). Digital literacy in Turkish lessons. Türkiye Ĕ̈itim Dergisi, 3(2), 31-46. 11..11111/ted.xx

Erişti Bedir S. (2014). Digital storytelling and creativity through e-learning. In T. V. Yüzer \& G. Kurubacak (Eds.), Handbook of research on emerging priorities and trends in distance education: Communication, pedagogy, and technology (pp. 20-140). IGI Global.

Fessakis, G., Gouli, E., \& Mavroudi, E. (2013). Problem solving by 5-6 years old kindergarten children in a computer programming environment: a case study. Computers \& Education, 63, 87-97. https://doi.org/10.1016/j.compedu.2012.11.016 
Fields, D. A., Kafai, Y. B., Strommer, A., Wolf, E., \& Seiner, B. (2014, August). Interactive storytelling for promoting creative expression in media and coding in youth online collaboratives in Scratch. Proceedings of constructionism.

Fraenkel, J., Wallen, N., \& Hyun, H. (2011). How to design and evaluate research in education. Mc Graw Hill.

Gay, L. R., Mills, G. E., \& Airasian, P. (2006). Educational research: competencies for analysis and applications. Pearson.

Greene, J. C., \& Caracelli, V. J. (1997). Advances in mixed-method evaluation: The challenges and benefits of integrating diverse paradigms. Jossey-Bass.

Greene, J. C., Caracelli, V. J., \& Graham, W. F. (1989). Toward a conceptual framework for mixed-method evaluation designs. Educational Evaluation and Policy Analysis, 11(3), 255-274. https://doi.org/10.3102\%2F01623737011003255

Hagge, J. (2017). Scratching beyond the surface of literacy: Programming for early adolescent gifted students. Gifted Child Today, 40(3), 154-162. https://doi.org/10.1177\%2F1076217517707233

Hartley, J., \& McWilliam, K. (2009). Computational power meets human contact. In J. Hartley \& K. McWilliam (Eds), Story circle: digital storytelling around the world (pp.3-15). Blackwell.

Hull, G., \& Nelson, M., E. (2005). Locating the semiotic power of multimodality. Written Communication, 22(2), 224-261. https://doi.org/10.1177\%2F0741088304274170

Hung, C. M., Hwang, G. J., \& Huang, I. (2012). A project-based digital storytelling approach for improving students' learning motivation, problem-solving competence and learning achievement. Educational Technology \& Society, 15(4), 368-379.

Jakes, D. S., \& Brennan, J. (2005). Capturing stories, capturing lives: An introduction to digital storytelling. http://www.jakesonline.org /dsttechforum.pdf.

Jenkins, M., \& Lonsdale, J. (2007). Evaluating the effectiveness of digital storytelling for student reflection. In ICT: Providing choices for learners and learning. Proceedings ASCILITE Singapore 2007 (pp. 440-444).

Kafai, Y., \& Burke, Q. (2014). Connected code: why children need to learn programming. The MIT Press.

Kajder, S. B. (2004). Enter here: Personal narrative and digital storytelling. English Journal, 93(3), 64-68. https://doi.org/10.2307/4128811

Karakoyun, F. (2014). Examining the views of elementary school students and preservice teachers about digital storytelling activities in online environment (Unpublished doctoral dissertation). Anadolu University.

Karakuş, M., Türkkan, B. T., \& Naml, N. A. (2020). Investigation of the effect of digital storytelling on cultural awareness and creative thinking. Eğitim ve Bilim, 45(203), 309-326. http://dx.doi.org/10.15390/EB.2020.8576

Kırışoğlu, O. T. (2002). Sanatta eğitim: görmek, öğrenmek, yaratmak [Education in the arts: seeing, learning, creating]. Pegem.

Kim, H., \& Lee, J. H. (2018). The value of digital storytelling as an L2 narrative practice. The Asia-Pacific Education Researcher, 27(1), 1-9. https://doi.org/10.1007/s40299-017-0360-3

LaFrance, J., \& Blizzard, J. (2013). Student perceptions of digital story telling as a learning-tool for educational leaders. NCPEA International Journal of Educational Leadership Preparation, 8(2), 25-43.

Lasica, J. D. (2006) Digital storytelling: A tutorial in 10 easy steps. http://www.techsoup.org/learningcenter/training/archives/page10096.cfm.

Lea, S. J., Stephenson, D., \& Troy, J. (2003). Higher education students' attitudes toward student centred learning: Beyond 'educational bulimia'? Studies in Higher Education, 28(3), 321-334. https://doi.org/10.1080/03075070309293

Lim, P. R., \& Noor, N. M. (2019). Digital storytelling as a creative teaching method in promoting secondary school students' writing skills. International Journal of Interactive Mobile Technologies, 13(07), 117-128. https://doi.org/10.3991/ijim.v13i07.10798

Liu, C. C., Liu, K. P., Chen, G. D., \& Liu, B. J. (2010). Children's collaborative storytelling with linear and nonlinear approaches. Procedia Social and Behavioral Sciences, 2(2), 4787-4792. https://doi.org/10.1016/j.sbspro.2010.03.771

Microsoft (2010). Tell a story, become a lifelong learner. Microsoft, digital storytelling teaching guide. http://www.microsoft.com/education/en-us/teachers/guides/Pages/digital_storytelling.aspx.

Miles, M. B., \& Huberman, A. M. (1994). Qualitative data analysis: A sourcebook. Sage.

Miller, E. A. (2009). Digital storytelling (Unpublished doctoral dissertation). University of Northern Iowa.

Moenig, J., \& Harvey, B. (2012). BYOB Build your own blocks (a/k/a SNAP!). http://byob.berkeley.edu/.

Moradi, H., \& Chen, H. (2019). Digital storytelling in language education. Behavioral Sciences, 9(12), 147. https://doi.org/10.3390/bs9120147

Motsamai, M. (2012). Encouraging creativity and innovation in Botswana through digital storytelling and usage of new media technology. (Master's dissertation), Keio University. 
Niemi, H., Harju, V., Vivitsou, M., Viitanen, K., Multisilta, J., \& Kuokkanen, A. (2014). Digital storytelling for 21st-century skills in virtual learning environments. Creative Education, 5, 657-671. http://dx.doi.org/10.4236/ce.2014.59078

Normann, A. (2011). Digital storytelling in second language learning: A qualitative study on students' reflections on potentials for learning (Master's dissertation), Norges Teknisk-Naturvitenskapelige Universitet.

Ohler, J. (2008). Digital storytelling in the classroom: new media pathways to literacy, learning and creativity. Corwin Press.

Resnick, M., Maloney, J., Monroy-Hernández, A., Rusk, N., Eastmond, E., Brennan, K., ... \& Kafai, Y. (2009). Scratch: programming for all. Communications of the ACM, 52(11), 60-67. https://doi.org/10.1145/1592761.1592779

Robin, B. (2006). The educational uses of digital storytelling. Society for Information Technology \& Teacher Education International Conference, (pp.709-716). Association for the Advancement of Computing in Education (AACE).

Robin, B. (2008). The effective uses of digital storytelling as a teaching and learning tool. In J. Flood, S. Heath, \& D. Lapp (Eds.), Handbook of research on teaching literacy through the communicative and visual arts (pp. 429- 440). Lawrence Erlbaum Associates.

Sadik, A. (2008). Digital storytelling: a meaningful technology-integrated approach for engaged student learning. Educational Technology Research and Development, 56, 487-506. https://doi.org/10.1007/s11423-0089091-8

Smeda, N., Dakich, E., \& Sharda, N. (2014). The effectiveness of digital storytelling in the classrooms: a comprehensive study. Smart Learning Environments, 1, 1-21. https://doi.org/10.1186/s40561-014-0006-3

Tatlı, Z., \& Aksoy, D. A. (2017). Using digital storytelling in foreign language speaking education. Marmara Üniversitesi Atatürk Eğitim Fakültesi Eğitim Bilimleri Dergisi, 45, 137-152. https://doi.org/10.15285/maruaebd.271060

Toki, E. I., \& Pange, J. (2014). Ict use in early childhood education: storytelling. Bridges / Tiltai, 66(1), $183-192$. https://doi.org/10.15181/tbb.v66i1.786

Thorne, E. (2014). Digital storytelling: a safe space for creative expression. https://scholarsbank.uoregon.edu/xmlui/bitstream/handle/1794/18474/AAD_Thorne_FinalProject_2014?s equence $=1 \&$ is Allowed $=\mathrm{y}$.

Ulum, E., \& Ercan Yalman, F. (2020). 7th graders' experiences in preparing digital stories on science issues. International Journal of Educational Spectrum, 2(1), 1-24.

Vinayakumar, R., Soman, K. P., \& Menon, P. (2018). Digital storytelling using scratch: engaging children towards digital storytelling. 9th International Conference on Computing, Communication and Networking Technologies (ICCCNT), (pp. 1-6). IEEE.

Vinogradova, P., Linville, H. A., \& Bickel, B. (2011). "Listen to my story and your will know me": Digital stories as student-centered collaborative projects. TESOL Journal, 2(2), 173-202.

Wang, S., \& Zhan, H. (2010). Enhancing teaching and learning with digital storytelling. International Journal of Information and Communication Technology Education (IJICTE), 6(2), 76-87. https://doi.org/10.4018/jicte.2010040107

Wu, W. C., \& Yang, Y. T. (2008). The impact of digital storytelling and of thinking styles on elementary school students' creative thinking, learning motivation, and academic achievement. Society for Information Technology \& Teacher Education International Conference (pp. 975-981). Association for the Advancement of Computing in Education (AACE).

Xu, Y., Park, H., \& Baek, Y. (2011). A new approach toward digital storytelling: an activity focused on writing self efficacy in a virtual learning environment. Educational Technology \& Society, 14(4), 181-191.

Yamaç, A. (2015). The effect of digital storytelling in improving the writing skills of third grade school students (Unpublished doctoral dissertation). Gazi University.

Yang, Y. T. C., Chen, Y. C., \& Hung, H. T. (2020). Digital storytelling as an interdisciplinary project to improve students' English speaking and creative thinking. Computer Assisted Language Learning, 1-23. https://doi.org/10.1080/09588221.2020.1750431

Yang, Y. T. C., \& Wu, W. C. I. (2012). Digital storytelling for enhancing student academic achievement, critical thinking, and learning motivation: A yearlong experimental study. Computers \& education, 59(2), 339352. https://doi.org/10.1016/j.compedu.2011.12.012

Yavuz Konokman, G. (2015). The effects of composing digital story based on inquiry based learning on prospective teachers' resistance behaviours and learning approaches (Unpublished doctoral dissertation). Mersin University.

Yüksel, P., Robin, B., \& McNeil, S. (2011). Educational uses of digital storytelling all around the world. Society for Information Technology \& Teacher Education International Conference (pp. 1264-1271). Association for the Advancement of Computing in Education (AACE). 


\section{TÜRKÇE GENIŞLETILMIŞ̧ ÖZET}

Teknolojinin gelişmesi ile dijital ortamlar hayatımızda daha fazla yer etmeye başlamıştır. Bu değişimden okuma ve yazma becerilerimizin yanı sıra dinleme ve konuşma becerilerimiz de etkilenmiştir. Teknoloji ile iç içe büyüyen neslin de dijital ortamlardan fayda sağlaması kaçınılmazdır.

Dijital okuryazar bireylerden sorgulama, analitik düşünme, farklı çözüm yolları bulma, yaratıcı düşünme becerilerine sahip olmaları beklenmektedir. Özellikle çocukların doğası gereği yaratıcı oldukları ve onların yaratıcı düşünme becerilerini ortaya çıkarmanın ve geliştirmenin önemi bilinmektedir.

Yaratıcı düşünme "yeni imgeler elde etme, bunları birleștirip ayrıştırma, bunu gerece aktarma, gereç üzerinde düşünme, çizgiler, şekiller, renkler arasında niteliksel ilişkiler kurma, uzamsal, anlatımsal ve estetik düzenlemeler bulmaya yöneliktir" (Kırışoğlu, 2002). Doğru kaynaklar sağlanarak ve yeteneklerini özgürce kullanacakları ortamlar yaratarak çocuklarda yaratıcılığın geliştirilebileceği düşünülmektedir. Teknoloji destekli öğrenme ortamları, öğrencilerin yaratıcılık becerilerini geliştirmelerini sağlayan yapılandırmacı yaklaşıma göre düzenlenmelidir (Lea vd., 2003). Bilgisayarı, "yeni ve geliştirilmiş kalem" olarak tanımlayan Burke (2012) bu dijital cihazlarla yaratıcı, eleştirel ve iş birliğine dayalı yazma çalışmalarının yapılabileceğini belirtmiştir. Dijital hikâye çalışmaları bireylerin aktif olduğu yaratıcı, eleştirel ve iş birliğine dayalı süreçler sunmaktadır. Ohler (2008) dijital hikâye anlatımını geleneksel hikâyenin dijital teknoloji ile birleştirildiği yaratıcı bir süreç olarak belirtmiştir. Öğrenciler dijital hikâye oluşturma sürecinde araştırma, analiz etme, yaratma ve birleştirme yoluyla görseller ile yazılı metni bir araya getirerek sürece dâhil olmaktadır (LaFrance ve Blizzard, 2013).

Literatür incelendiğinde dijital hikâyelerin çoğunlukla Windows Movie Maker, Windows Photo Story veya iMovie gibi masaüstü bilgisayar yazılımları ile oluşturulduğu görülmektedir (Lasica, 2006; Doğan, 2007; Sadik, 2008; Barrett, 2006; Microsoft, 2010; Wang ve Zhan, 2010; Xu vd., 2011; Hung vd., 2012; Yang ve $\mathrm{Wu}, 2012)$. Fakat son zamanlarda çalışmalarda, blok tabanlı programlamanın dijital hikâye oluşturma çalışmalarında kullanıldığg görülmektedir (Resnick vd., 2009; Moenig ve Harvey, 2012). Üst düzey düşünme becerilerinin geliştirilmesi için çalışmaların yoğunlaştığı günümüzde öğrencilerin bu becerilerinin bilgisayar programlama ile geliştirilebileceği belirtilmiştir (Fessakis vd., 2013; Kafai ve Burke, 2014). Dolayısı ile bu çalışma ana dil eğitiminde bilgisayarda kodlama yoluyla dijital hikâye anlatımının yaratıcı düşünme becerisi açısında araştırılması önemlidir. Bu araştırmanın amacı; dijital hikâye oluşturmanın yaratıcı düşünme becerisine olan katkısını incelemektir. Bu çalışmanın alt amaçları ise şu şekildedir:

1. Dijital hikâye oluşturmak ortaokul yedinci sınıf öğrencilerinin yaratıcı düşünme becerilerine katkı sağlamakta midır?

2. Dijital hikâye oluşturma uygulamaları yaratıcı düşünme becerisinin kalıcı olmasını sağlamakta mıdır? 3. Dijital hikâye oluşturma ile ilgili öğrenci görüşleri nasıldır?

4. Dijital hikâye oluşturma uygulamaları sürecinde sosyal ortam, etkinlik süreci, sözel-sözel olmayan iletişim süreci boyutlarına yönelik neler gözlenmiştir?

Karma yöntem ile tasarlanan bu araştırmanın çalışma grubunu amaçlı örnekleme yöntemi ile seçilen ortaokul yedinci sınıfta öğrenim gören 20 öğrenci oluşturmaktadır. Duran ve Ertan Özen (2018) tarafından Türkçe dersi öğretim programındaki kazanımlar dijital okuryazarlık becerileri bağlamında taranmış ve dijital okuryazarlık ile ilgili kazanım sayısının en fazla yedinci ve sekizinci sınıflarda yer aldığı görülmüştür. Bu nedenle araştırmamızın çalışma grubunu eğitim öğretim yılının bir dönemi boyunca kodlama eğitimi alan yedinci sınıf öğrencilerinden oluşturmak uygun görülmüştür.

$\mathrm{Bu}$ araştırmada nicel veri toplama aracı olarak geliştirilen "Dijital Hikâyelerde Yaratıcı Düşünme Becerisini Puanlama Anahtarı" kullanılmıştır. Nitel verileri toplayabilmek için "Uygulama Gözlem 
Formu” ve "Dijital Hikâye Oluşturmaya İlişsin Öğrenci Görüşlerini Belirleme Formu” kullanılmıştır.

Verilerin toplanması sürecinde çalışma grubu ile dört hafta boyunca pilot uygulama yapılmıştır. Çalışma grubu tarafindan kullanılan yedinci sınıf Türkçe ders kitabında yer alan ilk dört temaya ilişkin hikâye oluşturma etkinlikleri gerçekleştirilmiştir. Çalışma grubunda yer alan tüm öğrenciler ile yarı yapılandırılmış görüşmeler gerçekleştirilmiş, uygulama sürecinde video kaydı yapılmış ve kalıcılık testi uygulanmıştır.

Sonuçlara göre, dijital hikâyelerden alınan "akıcılık", "özgünlük”, "hayal gücü”, "analitik düşünme becerisi", "farklı bakış açısı", "medya unsurları" ve "içerik" puanları arasında anlamlı bir artış olduğu görülmüştür. Elde edilen bu sonuçlara göre dijital hikâye oluşturma becerisinin, yaratıcı düşünme üzerinde katkısı olduğu görülmektedir. Benzer şekilde Jenkins ve Lonsdale (2007), Wu ve Yang (2008), Coutinho (2010), Motsamai (2012), LaFrance ve Blizzard (2013), Fields vd. (2014), Karakoyun (2014), Thorne (2014), Yavuz Konokman (2015), Akyeampong (2018), Karakuş vd. (2020), Yang vd. (2020) tarafından gerçekleştirilen çalışmalarda da dijital hikâye oluşturma ile yaratıcı düşünme arasında olumlu yönde bir ilişki olduğu belirtilmiştir. Araştırmada ulaşılan önemli sonuçlardan bir diğeri de öğrencilerin kalıcılık testi puanları arasında anlamlı bir farkın olmasıdır.

Genel anlamda öğrencilerden elde edilen görüşler dijital hikâye oluşturma etkinliklerini eğlenceli bulduklarını, uygulama öncesi yapılan beyin firtınası etkinliğinin düşünmeyi sağladığını, taslak hikâye oluşturmanın yararlı olduğunu, hikâye tahtasının dijital hikâye sürecini kolaylaştırdığını, kontrol listesi sayesinde hikâye hakkında değerlendirme yapılabildiğini, farklı bakış açısı, analitik düşünme, akıc1lık, özgünlük boyutlarında gelişmenin yaşandığını, çoklu ortam ögelerinin hikâyeyi güzelleştirdiğini ve hikâye unsurlarının daha kolay fark edildiğini göstermektedir.

Yapılan gözlemlerde dijital hikâye ile sınıf içerisinde öğrenci etkileşimlerinin geliştiği, dijital hikâye oluşturma sürecine katılma isteklerinin arttığı görülmüştür. Öğrencilerin etkinliklerden hoşlandığını gösteren ifadeleri, jest ve mimiklerinde de artış yaşanmıştır.

Elde edilen bu sonuçlar dijital hikâye anlatımının yaratıcı düşünme becerisine katkısı olduğunu göstermektedir. Geleneksel yazma sürecinin günümüz teknoloji ortamına aktarılarak geliştirilebileceği, öğrencilerin akademik performanslarını, üst düzey düşünme becerilerini, öğrenme motivasyonlarını, öğrenme davranışlarını da geliştirebilecekleri bir ortamda aktif öğrenenler olmalarının sağlanabileceği düşünülmektedir. 